\title{
COMPARISON OF TWO TECHNIQUES FOR DIAGNOSIS OF GIARDIASIS IN DOGS
}

\author{
DECOCK C.*, CADIERGUES M.C.**, LARCHER M.*, VERMOT S.** \& FRANC M.**
}

\begin{abstract}
Summary:
Giardiasis is an intestinal parasitosis affecting dogs and able to infect human beings. Its diagnosis can not be done with the only clinical signs, the main of which is non characteristic diarrhoea. It implicates to perform further tests to detect the parasite. The zinc sulfate concentration technique (ZSCT) is the more effective one if performed on two or three successive days. Fecal ELISA kits have been developed to detect Giardia in humans and were found to be less sensitive than the ZSCT in dogs. In this study, we used 30 infected Beagles to compare the sensitivity of one, two or three fecal examinations following ZSCT and one or two ELISA tests. We conclude that if a single ZSCT is insufficient, two or three ZSCT and one or two ELISA using the commercial kit ProSpect ${ }^{\circledR}$ Giardia have almost the same sensitivity.
\end{abstract}

KEY WORDS : dog, giardiasis, diagnosis.
Résumé : COMPARAISON DE DEUX TEChNIQUeS DE DIAGNOSTIC DE LA GIARDIOSE CANINE

La giardiose est une parasitose intestinale qui touche notamment le chien et est susceptible de se transmettre à l'homme. Le diagnostic de cette maladie ne peut pas se faire grâce aux seuls signes cliniques dont le principal est une diarrhée non caractéristique. II nécessite le réalisation de tests destinés à détecter le parasite. La coproscopie microscopique selon la technique de flottation en solution de sulfate de zinc est la plus efficace si elle est réalisée deux ou trois jours consécutifs. Les kits ElISA fécaux, commercialisés pour l'homme, donnent de moins bons résultats. Lors de cette étude, réalisée sur 30 Beagles infectés, nous avons comparé les sensibilités d'une, deux ou trois coproscopies et celles d'un ou deux tests ELISA utilisant le kit commercial ProSpect ${ }^{\circledR}$ Giardia. Nos résultats montrent que si une seule coproscopie est insuffisante, la réalisation de deux ou trois coproscopies, comme celle d'un ou deux tests ELISA présentent des sensibilités proches.

MOTS CLÉS : chien, giardiose, diagnostic.
G Tiardia duodenalis is a protozoan parasite found in the small intestine of mammals including dogs and human beings. In canine populations, the prevalence of this parasite reaches $13 \%$ to $17 \%$ (Beugnet et al., 2000; Villeneuve et al., 2000) but puppies in kennels are more affected than adults. The infestation occurs by ingestion of feces or water containing cysts. This disease is often considered as a zoonosis (Avedissian, 1988; Faubert, 1988; Thompson et al., 2000). Many infections of dogs with Giardia are probably not associated with clinical signs (Barr et al., 1994; Bourdeau, 1993; Bourdoiseau, 2000; Leib et al., 1999; Zajac, 1992). When symptoms occur, diarrhoea is the more frequent one. Feces are pale, soft and smelling. They may have a greasy appearance reminding of steatorrhea.

The most commonly used treatment in dogs is metronidazole (Zimmer et al., 1986; Jayagopala et al., 1992). Other drugs as tinidazole (Zimmer et al., 1986), furazolidone (Kirkpatrick et al., 1984), ipronidazole (Abbitt et al., 1986) and quinacrine (Zimmer et al., 1986) are

\footnotetext{
* Unité de Dermatologie-Parasitologie, École Nationale Vétérinaire de Toulouse, France.

** UMR 181, École Nationale Vétérinaire de Toulouse, 23, chemin des Capelles, 31076 Toulouse Cedex 3, France.

Correspondence: Michel Franc.

E-mail: m.franc@envt.fr
}

also effective. Benzimidazole anthelmintics have also been recommended for their activity against Giardia. Fenbendazole (Barr et al., 1994; Zajac et al., 1998), oxfendazole (Villeneuve et al., 2000), febantel (associated with praziquantel and pyrantel pamoate) (Barr et al., 1998) and albendazole (Barr et al., 1993) were generally investigated with success when they were used at the anthelmintic dosage.

To be effective, treatment must be associated with hygienic measures in order to avoid recontamination. Giardiasis can not be diagnosed with the only clinical signs. It implicates to perform tests to prove the presence of the parasite. The zinc sulfate concentration technique (ZSCT) is the more effective one if performed on two or three successive days (Zimmer \& Burrington, 1986). Other methods have practical or sensitivity problems as peroral string test (Barr et al., 1992), endoscopic duodenal aspiration (Pitts et al., 1983; Zajac et al., 1992) and fecal smear (Zimmer \& Burrington, 1986). Fecal ELISA kits, that detect Giardia specific antigen (GSA 65), have been developed to detect Giardia in humans and were found to be less sensitive than the ZSCT in dogs (Barr et al., 1992; Hopkins et al., 1993).

In this study, we have compared the sensitivity of one, two or three fecal examinations following ZSCT and 
one or two commercial ELISA tests (ProSpecT ${ }^{\circledR}$ Giardia) that detects also GSA 65 antigen ${ }^{\text {a }}$.

\section{MATERIAL AND METHODS}

1 hirty Beagles (15 males and 15 females), between 16 and 17 weeks old, were included. All dogs were coming from a kennel dedicated to laboratory sale. They were vaccinated against distemper, hepatitis, parvovirus infection, leptospirosis and rabies virus infection. All were clinically in good health at the beginning of the trial. They lived in boxes of six dogs which were daily washed with water under pressure and weekly disinfected with quaternary ammoniums ${ }^{b}$. The day before each fecal sample collection they were placed in individual cages. They were fed with commercial dry dog food ${ }^{c}$. Three examinations using the ZSCT on fresh fecal samples were made on day 0 , day 1 and day 2 . In the same time, detection of GSA65 antigen with ELISA tests was performed on day 1 and day 2 using the manufacturer's recommended procedure ${ }^{\mathrm{b}}$. $0.1 \mathrm{~g}$ of feces were mixed with $0.4 \mathrm{ml}$ of dilution Buffer. Then, it was placed in wells and added with $0.1 \mathrm{ml}$ of dilution Buffer. After one hour incubation period, wells were rinced three times with $0.4 \mathrm{ml}$ of wash Buffer solution, then four drops of enzyme conjugate were added. 30 minutes later, wells were rinced five times. Then, four drops of color substrate were added before a ten minutes incubation period. One drop of stop solution was mixed in each well. The microplate was read spectrophotometrically at a $450 \mathrm{~nm}$ O.D. within 10 minutes. Concerning the ZSCT, we mixed one gram of feces in $10 \mathrm{ml}$ of $33 \%$ zinc sulfate solution and let it during 10 minutes before the observation of 10 microscopic fields with the X40 objective.

Later, both methods were applied to the feces on day 20 and day 21.

To compare the two methods of diagnosis we used the $\chi^{2}$ test. Comparisons were considered as significant if $\mathrm{P}<0.05$.

\section{RESULTS}

I ndividuals results are shown in Table I and Table IV. There was no significant difference between the number of positive animals detected by three successive ZSCT (100 \%), two successive ZSCT (94\%), one ELISA (93\%) or two successive ELISA (97\%) (Tables II

${ }^{a}$ ProSpec ${ }^{\circledR}$ Giardia Microplate Assay. Alexon-Trend, Inc. Ramsey, MN 55303-Distribution: Elitech, ZI de Perbost 31800 Labarthe Inard. ${ }^{b}$ Aseptol ${ }^{\circledR}$ BLD 80 Laboratoires Mériel S.A., F-02370 Vailly-sur-Aisne. ${ }^{c}$ Medium Junior. Royal Canin, F-30470 Aymargues. and III). However, a single ZSCT ( $72 \%$ ) is sensibly less effective that the other tested methods $(\mathrm{P}<0.05)$. When compared to two ZSCT, one ZSCT is still less sensitive

\begin{tabular}{|c|c|c|c|c|c|}
\hline \multirow[b]{2}{*}{ Dogs } & \multicolumn{3}{|c|}{ ZSCT } & \multicolumn{2}{|c|}{ ELISA } \\
\hline & Do & D1 & $\mathrm{D} 2$ & D1 & D2 \\
\hline $131-146-142-121-126-152-145-120-144$ & + & + & + & + & + \\
\hline 139 & + & + & + & + & - \\
\hline $151-143$ & + & + & - & + & + \\
\hline $156-141-138-119-170$ & + & - & + & + & + \\
\hline $136-147-162-133-149-129$ & - & + & + & + & + \\
\hline 148 & - & + & + & - & - \\
\hline 161 & + & - & - & - & + \\
\hline $130-164-173$ & - & + & - & + & + \\
\hline 122 & - & - & + & + & + \\
\hline 140 & - & - & - & + & + \\
\hline Positive dogs & 18 & 22 & 23 & 28 & 28 \\
\hline
\end{tabular}

Table I. - Results of the tests for detection of Giardia in 30 dogs on day 0 , day 1 and day 2 (+: positive; -: negative).

\begin{tabular}{lrcc}
\hline & 3 ZSCT & 2 ZSCT & 1 ZSCT \\
\hline Number of positive dogs & 29 & $28,28,26$ & $18,22,23$ \\
Mean percentage of positive dogs & 100 & 94 & $72^{*}$ \\
\hline
\end{tabular}

Table II. - Comparison of the sensibility of 1, 2 or 3 ZSCT for detection of Giardia. ${ }^{a}$ We considered that a dog was positive if at least one of the three ZSCT was positive. * Significant difference between this result and $100 \%(\mathrm{P}<0.05)$.

\begin{tabular}{|c|c|c|c|c|}
\hline \multicolumn{2}{|c|}{ Tests results } & \multicolumn{3}{|c|}{ Number of dogs } \\
\hline $\begin{array}{c}\text { 3 ZSCT } \\
\text { (D0 and/or D1 } \\
\text { and/or D2) }\end{array}$ & $\begin{array}{c}\text { ELISA } \\
\text { (D1 and/or D2) }\end{array}$ & $\begin{array}{l}1 \text { ELISA } \\
\text { (D1) }\end{array}$ & $\begin{array}{c}1 \text { ELISA } \\
\text { (D2) }\end{array}$ & $\begin{array}{c}2 \text { ELISA } \\
\text { (D1 and/or D2) }\end{array}$ \\
\hline Positive & Positive & 27 & 27 & 28 \\
\hline Positive & Negative & 2 & 2 & 1 \\
\hline Negative & Positive & 1 & 1 & 1 \\
\hline Negative & Negative & 0 & 0 & 0 \\
\hline \multicolumn{2}{|c|}{ Sensitivity } & $93 \%$ & $93 \%$ & $97 \%$ \\
\hline
\end{tabular}

Table III. - Comparison of 3 ZSCT and 1 or 2 ELISA for detection of Giardia in dogs.

\begin{tabular}{|c|c|c|c|c|}
\hline \multirow[b]{2}{*}{ Dogs } & \multicolumn{2}{|c|}{ ZSCT } & \multicolumn{2}{|c|}{ ELISA } \\
\hline & D20 & D21 & D20 & D21 \\
\hline $131-151-148-143-164-161-162-145-120$ & + & + & + & + \\
\hline 141 & + & + & - & + \\
\hline $156-146-140-121$ & + & - & + & + \\
\hline 130-138-136-147-173-149-129-144 & - & + & + & + \\
\hline $122-139-133-152$ & - & - & + & + \\
\hline $119-170$ & - & - & - & + \\
\hline 126 & - & - & - & - \\
\hline Positive dogs & 14 & 18 & 25 & 28 \\
\hline
\end{tabular}

Table IV. - Results of the tests for detection of Giardia in 29 dogs on day 20 and day 21 (+: positive; -: negative). 


\begin{tabular}{lrc}
\hline & 2 ZSCT & 1 ZSCT \\
\hline Number of positive dogs & 50 & 36,41 \\
Mean percentage of positive dogs & 100 & $77^{*}$ \\
\hline
\end{tabular}

Table V. - Comparison between 1 and 2 ZSCT using the results on days $1,2,20$ and 21 . ${ }^{a}$ We considered that a dog was positive if at least one on the two ZSCT was positive. ${ }^{*}$ Significant difference between this result and $100 \%(\mathrm{P}<0.05)$.

\begin{tabular}{|c|c|c|c|c|}
\hline \multicolumn{2}{|c|}{ Tests results } & \multicolumn{3}{|c|}{ Number of dogs } \\
\hline $\begin{array}{c}2 \mathbf{Z S C T} \\
(\mathrm{D} 20 \text { and/or } \\
\mathrm{D} 21)\end{array}$ & $\begin{array}{c}\text { ELISA } \\
\text { (D20 and/or } \\
\text { D21) }\end{array}$ & $\begin{array}{c}1 \text { ELISA } \\
(\mathrm{D} 20)\end{array}$ & $\begin{array}{c}1 \text { ELISA } \\
(\mathrm{D} 21)\end{array}$ & $\begin{array}{c}2 \text { ELISA } \\
\text { (D20 and/or } \\
\text { D21) }\end{array}$ \\
\hline Positive & Positive & 48 & 48 & 49 \\
\hline Positive & Negative & 2 & 2 & 1 \\
\hline Negative & Positive & 5 & 8 & 8 \\
\hline Negative & Negative & 4 & 1 & 1 \\
\hline \multicolumn{2}{|c|}{ Sensitivity } & $96 \%$ & $96 \%$ & $98 \%$ \\
\hline
\end{tabular}

Table VI. - Comparison of 2 ZSCT and 1 or 2 ELISA for detection of Giardia in dogs.

(77\%) whereas one ELISA (96\%) or two ELISA (98\%) are equivalent (Tables $\mathrm{V}$ and $\mathrm{VI}$ ).

\section{DISCUSSION}

T The zinc sulfate concentration technique during three consecutive days is often described as the reference method to detect Giardia in dog feces (Zimmer \& Burrington, 1986; Barr et al., 1992). In this study, we showed that two ZSCT at 24 hours give good results which are not sensibly different from those obtained with three ZSCT. On the other hand, we confirmed that a single ZSCT is not sufficient to make a good screening of the parasite. This may be due to the intermittent shedding of cysts by infected animals. Moreover, the microscopic examination of the slide does not assure to detect cysts when present unless watching the whole slide what is taking time.

The use of the ELISA test (ProSpecT ${ }^{\circledR}$ Giardia, AlexonTrend) gives sensitivity results near from that of two or three ZSCT. It makes it a reliable technique for diagnosis in dogs, but the practicality of the ELISA which is more complicate (even if results can be read visually), the long time test required (about two hours) and its high cost restrict the use of this method to particular cases. It may be advantageous for the control of a great number of animals or when the collection of fecal samples during two or three days is not possible. It appears necessary, combined with ZSCT for evaluation of treatment.

\section{ACKNOWLEDGEMENTS}

The authors would like to express their gratitude to Cécile Caubet, Martine Roques and Dr Greg Martin for their assistance.

\section{REFERENCES}

Abbitt B., Huey R.L., Eugster A.K. \& Sylver J. Treatment of giardiasis in adult Greyhounds, using ipronidazole-medicated water. Journal of American Veterinary Medical Association, 1986, 188, 67-69.

Avedissian D. Giardiose canine et féline. Th. : Med. vet. Lyon, 1988, 124, $90 \mathrm{p}$.

Barr S.C., Bowman D.D., Heller R.L. \& Erb H.N. Efficacy of albendazole against giardiasis in dogs. American Journal of Veterinary Research, 1993, 54, 926-928.

BarR S.C. \& Bowman D.D. Giardiasis in dogs and cats. Compendium on Continuing Education, 1994, 16, 603-610.

Barr S.C., Bowman D.D. \& Heller R.L. Efficacy of fenbendazole against giardiasis in dogs. American Journal of Veterinary Research, 1994, 55, 988-990.

Barr S.C., Bowman D.D., Frongillo M.F. \& Joseph S.L. Efficacy of a drug combination of praziquantel, pyrantel pamoate, and febantel against giardiasis in dogs. American Journal of Veterinary Research, 1998, 59, 1134-1136.

Beugnet F., Guillot J., Polack B \& Chermette R. Enquête sur le parasitisme digestif des chiens et des chats de particuliers de la région parisienne. Revue de Médecine Vétérinaire, 2000, 151, 443-446.

Bourdeau P. Les giardioses des carnivores. Recueil de Médecine Vétérinaire, 1993, 169, 393-400.

Bourdoiseau G. Parasitologie clinique du chien. Nouvelles éditions vétérinaires et alimentaires. Créteil, France, 2000, 456 p.

FAubert G.M. Evidence that giardiasis is a zoonosis. Parasitology Today, 1988, 4, 66-68.

Hopkins R.M., Deplazes P., Meloni B.P., Reynoldson J.A. \& ThOMPson R.C. A field and laboratory evaluation of a commercial ELISA for the detection of Giardia coproantigens in humans and dogs. Transactions of the Royal Society of Tropical Medecine and Hygiene, 1993, 87, 3941.

Jayagopala Reddy N.R., Thimmappa RaI M., Ranganath L., Chandrashekarmurthy V. \& Nagarajachar P. Treatment of giardiasis with metronidazole in dogs. Indian Veterinary Journal, 1992, 69, 163-164.

KirKPATRICK C.E. \& FarRell J.P. Feline giardiasis: observations on natural and induced infections. American Journal of Veterinary Research, 1984, 45, 2182-2188.

LEIB M.S. \& ZAJAC A.M. Giardiasis in dogs and cats. Veterinary Medicine, 1999, 94, 793-802.

Pitts R.P., Twedt D.C. \& Malle K.A. Comparison of duodenal aspiration with fecal flotation for diagnosis of giardiasis in dogs. Journal of American Veterinary Medical Association, 1983, 182, 1210-1211. 
Thompson R.C.A., Hopkins R.M. \& Homan W.L. Nomenclature and genetic groupings of Giardia infecting mammals. Parasitology Today, 2000, 16, 210-212.

Villeneuve V., Beugnet F. \& Bourdoiseau G. Efficacy of oxfendazole for the treatment of giardiosis in dogs. Experiments in dog breeding kennels. Parasite, 2000, 7, 221-226.

ZaJAC A.M. Giardiasis. Compendium on Continuing Education, 1992, 14, 604-610.

Zajac A.M., LaBranche T.P., Donoghue A.R. \& Chu T.C. Efficacy of fenbendazole in the treatment of experimental Giardia infection in dogs. American Journal of Veterinary Research, 1998, 59, 61-63.

Zimmer J.F. \& Burrington D.B. Comparison of four techniques of fecal examination for detecting canine giardiasis. Journal of the American Animal Hospital Association, 1986, 22, 161-167.

Zimmer J.F. \& Burrington D.B. Comparison of four protocols for the treatment of canine giardiasis. Journal of the American Animal Hospital Association, 1986, 22, 168-172.

Reçu le 15 octobre 2002 Accepté le 12 décembre 2002 